\title{
Production, Purification and Characterization of L-Asparaginase from Marine Endophytic Aspergillus sp. ALAA-2000 under Submerged and Solid State Fermentation
}

\author{
Mervat Morsy Abbas Ahmed ${ }^{1,2 *}$, Nageh Abo Dahab F³ , Taher Taha $\mathbf{M}^{3}$ and Fareed Hassan $\mathbf{S M}^{3}$ \\ ${ }^{1}$ Department of Biological Sciences, King Abdulaziz University (KAU), Saudi Arabia \\ ${ }^{2}$ Chemistry of Natural and Microbial Products Department, National Research Centre, Dokki, Giza, Egypt \\ ${ }^{3}$ Department of Botany and Microbiology, Faculty of Science, Al-Azhar University, Assuit, Egypt
}

\begin{abstract}
Among all endophytic fungi recovered from the marine soft sponge Aplysina fistularis, $72.2 \%$ were able to produce L-asparaginase. Among all obtained isolates, Aspergillus sp. ALAA-2000, the hyperactive producer for the anticancer agent, L-asparaginase, under submerged fermentation (SMF) and solid state fermentation (SSF) of different agriculture wastes was selected for the optimization of extraction process; optimization of physicochemical parameters, which affecting the production of L-asparaginases in SSF and optimization of the purified $\mathrm{L}$-asparaginases parameters. Maximum L-asparaginase activity $23.34 \mathrm{U} / \mathrm{ml}$ was recovered from soybean with hot water at $40{ }^{\circ} \mathrm{C}$ and $150 \mathrm{rpm}$ for $30 \mathrm{~min}$ under SSF and $30.64 \mathrm{U} / \mathrm{ml}$ under submerged fermentation using glucose as carbon source and asparagine as nitrogen source. Two types of L-asparaginase (AYA-1 and AYA-2) were purified from the culture supernatant of Aspergillus sp. ALAA-2000 through ammonium sulfate precipitation and gel filtration chromatography (sephadex G-200). Molecular weights of the enzymes were $25 \mathrm{kDa}$ (AYA-1) and $31 \mathrm{kDa}$ (AYA-2). The parameters of purified L-asparaginase were optimized for AYA-1 $\left(\mathrm{pH} 6.0\right.$, stable at $30^{\circ} \mathrm{C}$ to $50^{\circ} \mathrm{C}$ for $60 \mathrm{~min}$, reaction time $15 \mathrm{~min}$, and substrate concentration $1.275 \mathrm{mg} / \mathrm{ml}$ ) and AYA-2 enzyme (pH 10, stable at $30^{\circ} \mathrm{C}$ to $70^{\circ} \mathrm{C}$ for $60 \mathrm{~min}$, reaction time $15 \mathrm{~min}$, and substrate concentration $1.275 \mathrm{mg} / \mathrm{ml}$ ). Whereas inhibitors of metaloproteases, chelating agents EDTA, had no effect on L-asparaginase. These finding suggest that L-asparaginase was not metaloproteases.
\end{abstract}

Keywords: Marine endophytic Aspergillus sp.; L-asparaginase; Solid state and submerged fermentation; Process parameters; Purification

\section{Introduction}

Chemotherapy is one of the principal modes of treatment for cancer. It is the process of using anticancer drugs to stop cells from dividing and multiplying but there are few curative chemotherapeutic drugs against cancer due to high toxicity, non selectivity, numerous side effects and low activity [1]. Therefore, searching and developing effective anticancer agents for these particular diseases have a great impact on morbidity and mortality of the patients and could therefore save many lives. Almost $60 \%$ of drug approved for cancer treatment are of natural origin. Although marine compounds are underrepresented in current pharmacopoeia, it is anticipated that the marine environment will become an invaluable source of novel compounds in the future, as it represents more than $70 \%$ of the biosphere. The marine endophytic microflora in the coming decades will be the nature's best source of chemicals. Natural products metabolized from endophytic microorganisms represent desirable sources for effective therapeutic enzymes [2-4]. Marine fungi are rich profile of biologically active metabolites, especially from genera Penicillium, Aspergillus and Fusarium have been used aiming the development of novel therapies for treating cancer. Whereas the marine fungi are least studied than terrestrial counterparts and other ecological group, they have to study due to their production of new metabolites which are not found in terrestrial fungi [5]. Therapeutic enzymes are utilized in the treatment of diseases such as cancer, severe disorders like autism, chronic lung disease and multiple sclerosis but the major potential therapeutic application of enzymes is in the treatment of cancer. Interestingly, therapeutic enzymes have a particular ability to mediate high affinity interactions with unrelated proteins relevant in cancer conferring on it the property. The chemotherapeutic agents in miscellaneous include therapeutically enzymes as L-asparaginase (E.C.3.5.1.1) which is degrades the particular amino acid L-asparagine and corticosteroid that act on specific cellular receptors to disrupts DNA in the majority of tumor cells [6]. The rationale behind L-asparaginase depends upon the fact that tumor cells are deficient in aspartate ammonia ligase activity which restricts their ability to synthesis the normally non-essential amino acid L-asparagine. These leukemic cells depend on circulating $\mathrm{L}$-asparagine. The action of the $\mathrm{L}$-asparaginase does not affected the functioning of normal cells which are able to synthesis enough for their own requirements but reduce the free exogenous concentration and so induces a state of fatal starvation in the susceptible tumor cells. Along with strain improvement by optimization of production parameters, the yield of L-asparaginase productivity was maximized.

The aim of this study is to isolate, identify and evaluate the potential of culturable marine endophytic fungi isolated from the internal healthy tissue of marine invertebrates for production of L-asparaginase as potent anticancer agents as well as develop an economically viable bioprocess for production of $\mathrm{L}$-asparaginase by evaluating and

*Corresponding author: Mervat Morsy Abbas Ahmed, Department of Biological Sciences, King Abdulaziz University (KAU), Saudi Arabia, Tel: +966 26400000 E-mail: m_morsy_70@yahoo.com

Received March 20, 2015; Accepted April 22, 2015; Published April 29, 2015

Citation: Abbas Ahmed MM, Nageh Abo Dahab F, Taher Taha M, Fareed Hassan SM (2015) Production, Purification and Characterization of L-Asparaginase from Marine Endophytic Aspergillus sp. ALAA-2000 under Submerged and Solid State Fermentation. J Microb Biochem Technol 7: 165-172. doi:10.4172/19485948.1000199

Copyright: (C) 2015 Abbas Ahmed MM, et al. This is an open-access article distributed under the terms of the Creative Commons Attribution License, which permits unrestricted use, distribution, and reproduction in any medium, provided the original author and source are credited 
Citation: Abbas Ahmed MM, Nageh Abo Dahab F, Taher Taha M, Fareed Hassan SM (2015) Production, Purification and Characterization of L-Asparaginase from Marine Endophytic Aspergillus sp. ALAA-2000 under Submerged and Solid State Fermentation. J Microb Biochem Technol 7: 165-172. doi:10.4172/1948-5948.1000199

optimizing process parameters through manipulating the nutritional and physical parameters using low cost substrates.

\section{Materials and Methods}

\section{Isolation of marine endophytic fungi}

The marine endophytic molds were maintained from the marine sponge as previously described by Holler et al. [7] and El-Bondkly and El-Gendy [8]. The healthy specimens of Egyptian sponge Aplysina fistularis were collected from Hurghada, Red Sea, Egypt, washed with distilled water and cut into small pieces of ca. $4 \times 4 \mathrm{~mm}^{2}$. Tissue pieces were rinsed in $0.1 \%$ Tween 20 for $1 \mathrm{~min}$, then in $2.5 \%$ sodium hypochlorite for $15 \mathrm{~min}$ followed by washing in sterile distilled water for $5 \mathrm{~min}$. Surface was sterilized with $75 \%$ ethanol for $5 \mathrm{~min}$ then rinsed in sterile water for three times. Finally the pieces were transferred to dishes of three different isolation media, potato dextrose agar, malt agar and peptone yeast extract glucose agar, which containing $100 \mu \mathrm{g} /$ $\mathrm{ml}$ of oxytetracycline to inhibit the bacterial growth until the fungal mycelium or colony originated from the injury surface and incubated at $30^{\circ} \mathrm{C}$ for two weeks. Another segment of the same origin without surface sterilization was cultured as a negative control to check the presence of contaminated microbes on the sterilized segment surface. Single colonies were transferred periodically to the same medium and after 7 days at $30^{\circ} \mathrm{C}$. The obtained isolates were purified, maintained at $4{ }^{\circ} \mathrm{C}$ and examined for the production of L-asparaginase enzyme.

\section{Screening of fungal isolates for $\mathrm{L}$-asparaginase activity}

Screening of fungal isolates for L-asparaginase activity was performed using the modified Czapek Dox medium (glucose $2 \mathrm{~g}$, L-asparagine $10 \mathrm{~g}, \mathrm{KH}_{2} \mathrm{PO}_{4} 1.52 \mathrm{~g}, \mathrm{KCl} 0.52 \mathrm{~g}, \mathrm{MgSO}_{4} \cdot 7 \mathrm{H}_{2} \mathrm{O} 0.52 \mathrm{~g}$, $\mathrm{FeSO}_{4} .7 \mathrm{H}_{2} \mathrm{O} 0.01 \mathrm{~g}$, agar $20 \mathrm{~g}$, distilled water $1000 \mathrm{~mL}$ ) for the plate assay. $3 \mathrm{~mL}$ of $2.5 \%$ stock solution of phenol red in ethanol ( $\mathrm{pH} 6.2$ ) was added to $1000 \mathrm{~mL}$ of Czapek Dox medium. After $72 \mathrm{~h}$ of incubation at $26 \pm 1^{\circ} \mathrm{C}$, the appearance of a pink zone around the fungal colony in an otherwise yellow medium indicated L-asparaginase activity [9].

\section{Molecular identification of the hyper L-asparaginase producer strain}

The selected hyper producer strain ALAA-2000 was identified according to its phenotypic and genotypic characteristics. The fungal strain ALAA-2000 was identified using internal transcribed spacer (ITS) sequences. The genomic DNA of this fungus was isolated and purified from protoplasts using a QIAGEN DNeasy Tissue Kit following the manufacturer's protocol for Gram-positive bacteria and animal tissue [10,11]. Amplification of ribosomal DNA was performed using puReTaq $^{\mathrm{TM}}$ Ready-To-Go ${ }^{\mathrm{TM}}$ PCR Beads (Amersham Biosciences).The internal transcribed spacers (ITS) of the nuclear rDNA was identified according to the method described by Henry et al. [12] and White et al. [13] with some modifications. Next, polymerase chain reaction (PCR) was conducted using the ITS1 (5'-TCCGTAGGTGAACCTGCG-3') and ITS4 (5'-TCCTCCGCTTATTGATATGC-3') primers [13], for amplification of the PCR product, $661 \mathrm{bp}$ in size. The conditions for this PCR were: initial denaturation $\left(5 \mathrm{~min}\right.$ at $94^{\circ} \mathrm{C}$ ) followed by 45 cycles of primer annealing $\left(1 \mathrm{~min}\right.$ at $\left.55^{\circ} \mathrm{C}\right)$, primer extension $\left(2 \mathrm{~min}\right.$ at $\left.72^{\circ} \mathrm{C}\right)$ and denaturation $\left(1 \mathrm{~min}\right.$ at $\left.94^{\circ} \mathrm{C}\right)$, a final primer annealing $(1 \mathrm{~min}$ at $\left.42^{\circ} \mathrm{C}\right)$ and a final extension phase $\left(5 \mathrm{~min}\right.$ at $\left.72^{\circ} \mathrm{C}\right)$ and then cooled to $4^{\circ} \mathrm{C}$. PCR products were checked for correct length on a $1.5 \%$ Trisborate-EDTA TBE) agarose gel (1.5\% agarose, $8.9 \mathrm{mM}$ Tris, $8.9 \mathrm{mM}$ borate, $0.2 \mathrm{mM}$ EDTA), stained with ethidium bromide and visualized under UV illumination. Sequence data were edited with Lasergene
Software SeqMan (DNAStar Inc.). Next relatives were determined by comparison to rRNA genes in the NCBI GenBank database using BLAST (Basic Local Alignment Search Tool, http://www.ncbi.nlm.nih. gov website) to create a matrix using MEGA6 and ClustalW programs. The tree topologies were evaluated by bootstrap analyses based on 1,000 replications with MEGA6 and phylogenetic tree were inferred using the neighbor-joining method. The rDNA sequence of hyper enzymes producing strain ALAA-2000 have been deposited in GenBank database under the following Accession number: KF877334.

\section{L-Asparaginase assay}

The activity of L-asparaginase was determined by estimating the amount of $\mathrm{NH}_{3}$ liberated from asparagine during $\mathrm{L}$-asparaginase catalysis using Nessler's reagent. For L-asparaginase determination the reaction mixture composed of $0.01 \mathrm{M} \mathrm{L}$-asparagine and $0.05 \mathrm{M}$ Tris- $\mathrm{HCl}$ buffer ( $\mathrm{pH}$ 8.6), which incubated for $10 \mathrm{~min}$ at $37^{\circ} \mathrm{C}$. The reaction was stopped by the addition of $0.5 \mathrm{ml}$ of $15 \%$ trichloroacetic acid solution and the liberated ammonia was coupled with Nessler's reagent and quantitatively determined at $480 \mathrm{~nm}$. One international unit of L-asparaginase was defined as the amount of enzyme that liberates one micromole of ammonia from its substrate under the assay conditions [14].

\section{Protein determination}

Protein was determined by the absorbance at $280 \mathrm{~nm}$ using bovine serum albumin (BSA) as the standard [15]. All the sets have been performed in triplicates.

\section{Some factors affecting production of $L$-asparaginase by Aspergillus sp. ALAA-2000 strain}

Enzyme production under Solid state fermentation: The production of L-asparaginase by Aspergillus sp. ALAA-2000 under solid state fermentation was performed using different agro-industrial residues as sugar cane bagasse, wheat bran, corn cobs, soy bean, kidney bean bran, wheat hay, rice bran, rice straw and corn casing, which were collected from local suppliers and dried, grinded, sieved and preserved. Fermentation was conducted in $250 \mathrm{ml}$ Erlenmeyer flasks containing 10 $\mathrm{g}$ of each solid substrate, separately. Each solid substrate was moistened with mineral salt solution composed of $10 \mathrm{ml}$ of $0.01 \mathrm{M}$ phosphate buffer $\mathrm{pH} 6.2$ [16].

Effect of different leaching agent: The leaching out of $\mathrm{L}$-asparaginase from the fermented solids was carried out with different extractants such as hot water $\left(40^{\circ} \mathrm{C}\right)$, ethanol, acetone, Tween $80(1 \%)$, sodium chloride $(0.1 \%)$, citrate buffer $\mathrm{pH} 3$, phosphate buffer $\mathrm{pH} 7$, glycine buffer $\mathrm{pH} 12$, and at a ratio of 1:5 (w/v).

Enzyme production under submerged fermentation: For the production of L-asparaginase by Aspergillus sp. ALAA-2000, different fermentation media as a modified Czapek Dox medium, mineral salts and starch nitrate ware applied [10]. As a result of this experiment, a selective medium for Aspergillus sp. ALAA-2000 strain was determined which favored higher yield of L-asparaginase production. Aspergillus sp. ALAA-2000 strain was incubated in $250 \mathrm{ml}$ Erlenmeyer flasks containing $50 \mathrm{ml}$ of Czapex Dox medium supplemented with $\mathrm{L}$-asparagine and incubated at $27^{\circ} \mathrm{C}$ and $120 \mathrm{rpm}$ on a rotary shaker for 4 days. At the end of fermentation period the clear supernatant after centrifugation at $4000 \mathrm{rpm}$ for $20 \mathrm{~min}$ was used as enzyme preparations.

Effect of incubation period (typical production curve): Aspergillus sp. ALAA-2000 strain was grown in a modified Czapek Dox broth medium under shaking at different intervals of $2,4,6,8$, 10,12 and 14 days. At each interval, final $\mathrm{pH}$, L-asparaginase activities 
Citation: Abbas Ahmed MM, Nageh Abo Dahab F, Taher Taha M, Fareed Hassan SM (2015) Production, Purification and Characterization of L-Asparaginase from Marine Endophytic Aspergillus sp. ALAA-2000 under Submerged and Solid State Fermentation. J Microb Biochem Technol 7: 165-172. doi:10.4172/1948-5948.1000199

were determined. As a result of this experiment, the suitable incubation period for each enzyme was determined and applied in the next experiments.

Effect of incubation temperatures and initial $\mathrm{pH}$ : The effect of different incubation temperatures ranged from $20^{\circ} \mathrm{C}$ to $37^{\circ} \mathrm{C}$ on L-asparaginase production by the marine Aspergillus sp. ALAA-2000 strain was studied in a modified Czapek Dox broth in shake culture. The initial $\mathrm{pH}$ of the growth medium (modified Czapek Dox broth) was adjusted to various $\mathrm{pH}$ values $(3,4,6,7$ and 9) using $0.1 \mathrm{M}$ of $\mathrm{NaOH}$ or $\mathrm{HCl}$. The enzymatic activity of L-asparaginase at each initial $\mathrm{pH}$ was determined. The suitable initial $\mathrm{pH}$, which support maximum enzymes production by Aspergillus sp. ALAA-2000 strain was determined and applied in the next experiments.

Effect of different nitrogen and carbon sources: Organic nitrogen sources; beef extract, yeast extract, peptone and urea as well as inorganic nitrogen sources; ammonium nitrate, ammonium sulfate, ammonium hydrogen citrate were examined for their ability separately to stimulate the enzyme production in modified Czapek Dox broth medium instead of L-asparagine as N-base. This study established the type of nitrogen source that stimulates the highest amounts of the enzyme production by the isolated marine Aspergillus sp. ALAA-2000 strain.

Effect of adding $10 \mathrm{~g} / \mathrm{L}$ of various carbon sources separately in modified Czapek Dox broth medium instead of its carbon source (glucose) on L-asparaginase production was examined. These include raffinose, xylose, mannitol, mannose, sucrose, maltose, sorbose, lactose, galactose, fructose, starch, pectin, cellulose and dextrose. Carbon source which stimulates maximum enzymes production by Aspergillus sp. ALAA-2000 strain was used in the following studies.

Effect of some amino acids and element supplementations: Number of 10 amino acids including lysine, isoleucine, glycine, thiamine, arginine, treptophan, proline, glutamic acid, cysteine, and methionine were examined as a sole nitrogen source for $\mathrm{L}$-asparaginase production. Each of them was added to the medium instead of its nitrogen source in such amount that the final concentration of N-base remained unchanged. Different concentrations $(0.025 \%, 0.05 \%, 0.1 \%$, $0.15 \%$ and $0.2 \%$ ) of the most suitable amino acid source were tested for their ability to enhance the L-asparaginase production for Aspergillus sp. ALAA-2000 strain.

Some element supplementations $\left(\mathrm{MgCl}_{2}, \mathrm{LiCl}, \mathrm{CaCl}_{2}, \mathrm{~K}_{2} \mathrm{HPO}_{4}\right.$, $\mathrm{BaCl}_{2}$, and $\mathrm{NaCl}$ ) were supplementation to the modified Czapek Dox broth medium to study their effects on L-asparaginase production by Aspergillus sp. ALAA-2000 strain. Different concentrations $(0.025 \%, 0.05 \%, 0.1 \%, 0.15 \%$ and $0.2 \%)$ of the most suitable element supplementation were tested for their ability to enhance the enzyme production by Aspergillus sp. ALAA-2000 strain.

\section{Purification and characterization of $\mathrm{L}$-asparaginase produced by Aspergillus sp. ALAA-2000 strain}

The concentrated enzyme was subjected to ammonium sulphate fractionation with concentration ranging between $20 \%$ and $100 \%$ according to the method of Gomori [17]. The precipitate of crude enzyme was dissolved in a minimum volume of $0.2 \mathrm{M}$ phosphate buffer (pH 6.0) and dialyzed overnight in a dialysis bag against the same buffer at $4{ }^{\circ} \mathrm{C}$. The dialyzed ammonium sulfate fraction was applied to a Sephadex G-200 column (Pharmacia, Sweden, 2.5 X $45 \mathrm{~cm}$ ) that was pre-equilibrated with a $0.01 \mathrm{M}$ Tris $-\mathrm{HCl}$ buffer $\mathrm{pH}$ 8.5. The protein elution was done with the same buffer at a flow rate of $5 \mathrm{ml} / \mathrm{min}$ [18]. The activity fractions of L-asparaginase were collected and pooled at 4
${ }^{\circ} \mathrm{C}$. It was assayed for protein at $280 \mathrm{~nm}$ as well as for $\mathrm{L}$-asparaginase activity as described before.

\section{Determination of the molecular weight of the purified enzyme}

The molecular weights of the purified L-asparaginase were estimated by sodium dodecyl sulfate-polyacrylamide gel electrophoresis (SDSPAGE) as described by Laemmli [19].

\section{Characterization of partially purified L-asparaginase}

Optimum reaction time, $\mathrm{pH}$ and temperature: The optimum reaction time for the partially purified enzyme was estimated at different times $5,10,15,20,25,30,35,40,45$ and $50 \mathrm{~min}$ for L-asparaginase and then assayed by the direct nesslerization method. The optimum $\mathrm{pH}$ was determined by measuring enzymatic activity at $37^{\circ} \mathrm{C}$ using different buffers $(0.1 \mathrm{M})$ with various $\mathrm{pH}$ values as: citrate-phosphate buffer $(\mathrm{pH}$ 3, 4, 5 and 6), phosphate buffer ( $\mathrm{pH} 6-7)$, Tris- $\mathrm{HCl}$ buffer $(\mathrm{pH} 8$ 9) and glycine- $\mathrm{NaOH}$ buffer ( $\mathrm{pH} 10$ - 12). Optimum temperature was assayed by measuring activity with varying temperatures $(27,37,47,57$, 67,77 and $87^{\circ} \mathrm{C}$ ) at the optimum $\mathrm{pH}$ values.

Thermostability of partially purified L-asparaginase: Heat stability was determined by incubating the partially purified enzyme at various temperatures $\left(20,30,40,50,60,70,80\right.$ and $\left.90{ }^{\circ} \mathrm{C}\right)$ for 60 min and then the residual activity was determined at optimum $\mathrm{pH}$ and temperature.

Effect of substrate and enzyme concentrations: Partially purified $\mathrm{L}$-asparaginase was incubated individually with different concentrations of L-asparagine in the reaction mixture $(0.26,0.64,1.28,2.55,3.83$ and $5.10 \mathrm{mg} / \mathrm{ml}$ ) to find out the best substrate concentration for enzymatic assay under optimized assay conditions. Different concentrations $(0.001,0.03,0.05,0.1,0.15$ and $0.2 \mathrm{ml})$ of the partially purified $\mathrm{L}$-asparaginase were incubated individually with the optimization concentration substrate solution in the reaction mixture to determine the best enzyme concentration under the optimized assay condition.

Effect of some chemical additives on enzyme activity: The effect of different metal ions including $\mathrm{Na}^{+}, \mathrm{Ca}^{2+}, \mathrm{Mn}^{2+}, \mathrm{Mg}^{2+}, \mathrm{Co}^{2+}, \mathrm{Ba}^{2+}$, and $\mathrm{Ni}^{2+}$ at a final concentration of $1.0 \mathrm{mM}$ as well as EDTA at different concentrations $(0.0001,0.0010 .005,0.01,0.05$ and $0.1 \mathrm{M})$ separately on purified L-asparaginase were studied. Residual activities in the presence of each chemical was assayed and compared with the control (without additions), which considered as $100 \%$ activity.

\section{Results and Discussion}

\section{Isolation and screening of marine endophytic fungi for L-asparaginase activity}

This study proved that Egyptian marine sponge Aplysina fistularis is a rich source of endophytic microorganisms. Whereas 18 fungal isolates were obtained on the isolation media peptone yeast extract glucose agar, potato dextrose agar and malt agar. All these marine endophytic fungi were evaluated as fruitful source of the therapeutic antitumor enzyme L-asparaginase. Overall, the activity of L-asparaginase was detected in most fungal strains. Among all isolates, the fungal strain under the isolation number ALAA-2000 was the hyper active producer of $\mathrm{L}$-asparaginase. Therefore, this strain was selected for further studies. Endophytic fungi with different bioactive secondary metabolites are extremely distributed in all living organisms, whether terrestrial, marine plants corals and sponges [20-24]. Endophytes may be a novel and good producers of L-asparaginase. Of 82 endophyte isolates symptomless endophytic fungi isolated from seven green algae, six brown algae and 
Citation: Abbas Ahmed MM, Nageh Abo Dahab F, Taher Taha M, Fareed Hassan SM (2015) Production, Purification and Characterization of L-Asparaginase from Marine Endophytic Aspergillus sp. ALAA-2000 under Submerged and Solid State Fermentation. J Microb Biochem Technol 7: 165-172. doi:10.4172/1948-5948.1000199

six red algae production of L-asparaginase enzyme was detected in 64 isolates and Fusarium sp. isolated from the thallus of Sargassum wightii and a sterile mycelial isolated from the thallus of Chaetomorpha sp. showed maximum activity of the enzyme [25].

\section{Molecular identification of hyper L-asparaginase production strain ALAA-2000 through ITS region sequencing}

The ITS region of hyperactive enzymatic strain ALAA-2000 was amplified, sequenced, and submitted to GenBank (accession no. KF877334). Amplification with primers ITS1 and ITS4 resulted in approximately $661 \mathrm{bp}$ of fragment. The obtained sequences were compared with those in the National Center for Biotechnology Information (NCBI) Nucleotide Sequence Database by using the Basic Local Alignment Search Tool (BLAST) algorithm. A comparative analysis by MEGA6 and ClustalW software demonstrated that ITS region sequence from the producing strain ALAA-2000 had a significant identity to a number of Aspergilli (Figure 1). The comparison of the producing strain ALAA-2000 with sequences of the reference species of Aspergillus contained in genomic database banks exhibited a similarity of $99.52 \%$ with Aspergillus fumigatu M1, Aspergillus sojae JPDA1, Aspergillus flavus MJ49 and Aspergillus parasiticus DAOM 225948. According to the analysis genotypic together with phenotypic characteristics, the producing strain ALAA2000 was identified as Aspergillus sp. and designated as Aspergillus sp. ALAA-2000.

Production of antitumor enzyme, L-asparaginase, under different fermentation modes

Production of L-asparaginase under solid state fermentation (SSF): Data in Table (1) indicated the impact of using different natural

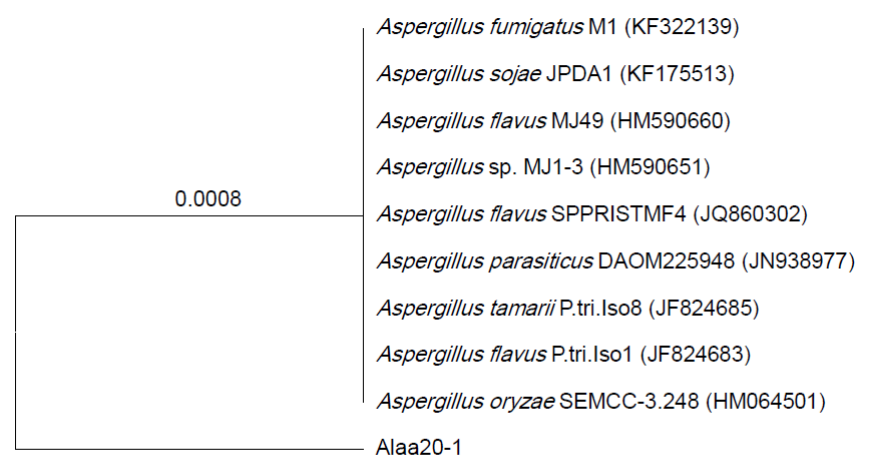

0.0002

Figure 1: phylogenetic tree to Aspergillus sp. ALAA-2000.

\begin{tabular}{|l|c|c|c|c|}
\hline \multirow{2}{*}{ Substrate } & \multicolumn{4}{|c|}{ Leaching agent } \\
\cline { 2 - 5 } & Hot water $\mathbf{4 0}^{\circ} \mathbf{C}$ & Glycine & Tween $\mathbf{8 0}$ & Citrate \\
\hline Sugar cane bagasse & 14.59 & 2.04 & 18.38 & 15.61 \\
Wheat bran & 10.21 & 0.15 & 22.76 & 15.03 \\
Corn cobs & 8.22 & 0.15 & 3.65 & 8.61 \\
Soy bean & 23.34 & 1.31 & 18.97 & 17.51 \\
Kidney bean bran & 9.33 & 1.02 & 13.57 & 22.03 \\
Wheat hay & 0.73 & 1.89 & 6.62 & 0.73 \\
Corn casing & 0.29 & 1.75 & 9.78 & 9.34 \\
Rice bran & 2.92 & 1.46 & 21.45 & 4.38 \\
\hline
\end{tabular}

Table 1: Production of L-asparaginase under solid state fermentation (SSF) and extracted with different leaching agents. sources as sugar cane bagasse, wheat bran, rice bran, corn cobs, soybean, kidney bean bran, wheat hay, corn casing and rice straw as a valuable and cheap energy sources for the production of this anticancer enzyme. On the other hand to optimize the enzyme yields leaching out from these fermented natural sources, each substrate was extracted with different leaching agents as hot water $40{ }^{\circ} \mathrm{C}$, ethanol, acetone, sodium chloride (1\%), Tween $80(1 \%)$, citrate buffer $(\mathrm{pH} 3)$, phosphate buffer $(\mathrm{pH} 7)$ and glycine buffer ( $\mathrm{pH} 12)$. Among these treatments, soybean as solid substrate extracted with hot water $\left(40^{\circ} \mathrm{C}\right)$ as leaching agent proved to be the best for achieving maximum L-asparaginase yield $(23.34 \mathrm{U} / \mathrm{ml})$ followed by wheat bran $(22.76 \mathrm{U} / \mathrm{ml})$, rice bran $(21.45 \mathrm{U} / \mathrm{ml})$, soybean $(18.97 \mathrm{U} / \mathrm{ml})$, sugar can bagasse $(18.38 \mathrm{U} / \mathrm{ml})$ after leaching out of the $\mathrm{L}$-asparaginase enzyme from these fermented substrates by Tween 80 (1\% ) with the exception of kidney bean bran, which extracted with citrate buffer $(\mathrm{pH} 3)$. Consequently agro industrial residues proved to be promising cheap sources for the industrial production of the therapeutic enzyme, especially soybean. Moreover, among all leaching hot water gave the best results with soybean but, Tween 80 (1\%), proved to be the fit leaching agent for L-asparaginase recovery from most fermented solid natural substrate under study followed by citrate buffer ( $\mathrm{pH} 3$ ).

The anticancer enzymes L-asparaginase was produced by a variety of fungi but the exclusive production of this enzyme in industry have been achieved mainly by Aspergillus species as Aspergillus terreus MTCC 1782 [26], Aspergillus sp. KUFS20 [27] and Aspergillus fumigates [28]. Soy bean was the best inducer for L-asparaginase production from Fusarium quiseti [29]. Negi and Banerjee [30] tested various parameters such as leaching agent selection, amount of leaching agent, soaking time, and temperature in order to determine optimum extraction conditions of enzymes produced by Aspergillus awamari nakazawa MTCC 6652 and optimum conditions were achieved in a 10\% glycerol.

Production of $\mathrm{L}$-asparaginase under submerged fermentation (SMF) versus typical course time: The effect of different three culture media named modified Czapek-Dox (M.Cz), mineral salts, and starch nitrate provided with $1 \% \mathrm{~L}$-asparagine on $\mathrm{L}$-asparaginase production by Aspergillus sp. ALAA-2000 was evaluated. Modified Dox medium showed the highest L-aspraginase activity $(35 \mathrm{U} / \mathrm{ml})$ while starch nitrate medium showed the lowest L-asparaginase productivity (17 $\mathrm{U} / \mathrm{ml}$ ). The activity of L-asparaginase increased with increasing the incubation period up to 10 days with maximal levels at the six day of fermentation under submerged fermentation. These data proved that SMF is preferred than SSF for L-asparaginase production from the marine endophytic fungus Aspergillus sp. ALAA-2000. Anamika et al. [31] and Elshafei et al. [32] reported the suitability of submerged fermentation for the produuction of L-asparaginase from Aspergillus terrus and Penicillium brevicompactum NRC 829, respectively but Siddalingeshwara and Lingappa [33] and Varalakshmi and Raju [26] favored SSF over SMF for the biosynthesis of L-asparaginase by Aspergillus terreus KLS2 and Aspergillus MTCC 1782, respectively. Many parameters that affect the submerged fermentation process were optimized. Typical time course of L-asparaginase production was an important criterion for assessment of potency of the producing strain Aspergillus sp. ALAA-2000. The highest biosyntheses of L-asparaginase was completed after 6 days of fermentation and thereafter decreased. These results are in accordance with the study conducted by Luhana et al. [34] on the production of L-asparaginase by Aspergillus niger, which reach its peak after 6 days of fermentation but differ from results obtained by Anamika et al. [31] and Patro and Gupta [35] for the maximum L-aspraginase production by Aspergillus terreus and Penicillium sp. after 3 and 10 days, respectively. 
Citation: Abbas Ahmed MM, Nageh Abo Dahab F, Taher Taha M, Fareed Hassan SM (2015) Production, Purification and Characterization of L-Asparaginase from Marine Endophytic Aspergillus sp. ALAA-2000 under Submerged and Solid State Fermentation. J Microb Biochem Technol 7: 165-172. doi:10.4172/1948-5948.1000199

Enzyme extraction treatments from whole broth after submerged fermentation for different incubation period: The industrial development of the microbial bioactive secondary metabolites has been hampered by the difficulty and expense of the releasing and extracting of bioactive compounds from the mycelium in good yield. The amounts of L-asparaginase released from the mycelium of ALAA-2000 treated with toluene, ethyl acetate and butanol were detected to be $4.81,9.19$ and $4.67 \mathrm{U} / \mathrm{ml}$, respectively compared to 13.71 detected in the cell free supernatant. These data clearly indicated that Most of the therapeutic enzyme L-asparaginase amount produces extracellular. Extracellular enzymes are of potent important in industrial application in the terms of minimize the cost of production process. Moreover L-asparaginase was reduced from 30.64 to $7.59,7.29$ and $6.13 \mathrm{U} / \mathrm{ml}$ at $10^{\text {th }}$ day of incubation period of whole broth with solvents.

Effect of different $\mathrm{pHs}$ and temperatures on L-asparaginase production from Aspergillus sp. ALAA-2000: Aspergillus sp. ALAA-2000 was incubated at different $\mathrm{pH}$ values $3,4,6,7,8$ and 9 with different incubation temperature 20,27 and $37^{\circ} \mathrm{C}$ for 6 days to determine the optimum temperature and $\mathrm{pH}$, which supported the highest L-asparaginase production. Data in Table (2) showed that initial $\mathrm{pH}$ between $\mathrm{pH} 3$ to $\mathrm{pH} 6$ at $27^{\circ} \mathrm{C}$ supported L-asparaginase production with a peak at $\mathrm{pH} 6(32.54 \mathrm{U} / \mathrm{ml})$ after 6 days of fermentation and then it was decreased gradually at higher temperature and $\mathrm{pH}$ values. Whereas maximum yields of L-aspraginase were achieved at the same incubation temperature $\left(27^{\circ} \mathrm{C}\right)$, they were elucidated at different with $\mathrm{pH}$ (6.0). In similar optimum incubation temperatures for L-asparaginase production from Fusarium sp was reported to be $27^{\circ} \mathrm{C}$ but for pencillum sp., Aspergillus niger, Aspergillus terreus MTCC 1782 and Aspergillus terreus were found to be $30,35,30$ and $30{ }^{\circ} \mathrm{C}$, respectively, [25,26,35-37].

Effect of different substrate concentrations on L-asparaginase production:

L-asparagine is the inducer for L-asparaginase production. Different concentrations $(0.5 \%, 1 \%, 1.5 \%, 2 \%$ and $2.5 \%)$ were added to the modified Dox medium individually to determine the optimum

\begin{tabular}{|c|c|c|c|}
\hline \multirow{2}{*}{$\mathbf{p H}$ value } & \multicolumn{3}{|c|}{ Enzyme production (U/mI) } \\
\cline { 2 - 4 } & $\mathbf{2 0}^{\circ} \mathbf{C}$ & $\mathbf{2 7}^{\circ} \mathbf{C}$ & $\mathbf{3 7}^{\circ} \mathbf{C}$ \\
\hline 3 & 4.82 & 17.79 & 18.38 \\
4 & 27.72 & 31.37 & 27.72 \\
6 & 21.89 & 32.54 & 26.26 \\
7 & 21.16 & 29.47 & 27.28 \\
9 & 16.78 & 28.01 & 18.53 \\
\hline
\end{tabular}

Table 2: Effect of different $\mathrm{pH}$ values and temperatures on $\mathrm{L}$-asparaginase production. concentration for the enzymes production. The maximum $\mathrm{L}$-asparaginase production was achieved with $1 \% \mathrm{~L}$-asparagine. On the other hand, higher L-asparagine concentrations (2\% and 2.5\%) did not increase the productivity (Table 3 ).

Effect of different nitrogen and carbon sources on $\mathrm{L}$-asparaginase production: The influence of different organic nitrogen sources and inorganic sources were studied. Each one of these nitrogen sources was added to the modified Dox medium individually at concentration instead of the enzymatic inducer L-asparagine. Results indicated that the endophytic Aspergillus sp. ALAA-2000 strain was required the inducers L-asparagine for the best biosyntheses of L-asparaginase $(33.85$ $\mathrm{U} / \mathrm{ml}$ ). However urea and sodium nitrate showed lowest production of L-asparaginase $(6.13$ and $7.59 \mathrm{U} / \mathrm{ml})$, respectively by Aspergillus sp. ALAA-2000 strain. Interestingly medium free nitrogen yielded $1.17 \mathrm{U} / \mathrm{ml}$ of L-asparaginase (Table 3). On the other hand, Aspergillus sp. ALAA-2000 strain was grown in modified czapek Dox medium supplemented with different carbon sources individually. From data in Table (3), it was obvious that galactose maximized L-asparaginase production by Aspergillus sp. ALAA-2000 strain to $32.83 \mathrm{U} / \mathrm{ml}$ followed by dextrose $(31.08 \mathrm{U} / \mathrm{ml})$ but mannose followed by mannitol were minimized its productivity to $(17.65$ and $14.14 \mathrm{U} / \mathrm{ml})$, respectively. Overall, all carbon sources did not exhibited much significant increase in enzyme production due to Dox.Cz modify medium free carbon relatively yielded a high amount of L-asparaginase $(29.33 \mathrm{U} / \mathrm{ml})$, this phenomenon in Aspergillus sp. ALAA-2000 strain is promising for cost effective of production process.

Carbon source represents the energy source that will be available for growth of the microorganism. Aspergillus oryzae produced the highest amounts of L-asparaginase under SMF using lactose as carbon source along with combination of tryptone $1 \%(\mathrm{w} / \mathrm{v})$ and yeast extract $0.5 \%$ $(w / v)$ as nitrogen source as well as L-asparagine as the best inducer [9]. Glucose as a carbon source in the medium inhibit L-asparaginase synthesis in fungi as Fusarium sp. and the enzyme activity increased with decreasing concentration of glucose in the growth medium [25]. Also, $0.5 \%$ Sucrose exhibited highest L-asparaginase activity (20.6 U/ $\mathrm{ml}$ ) by Aspergillus tamari [31] but glucose at a concentration of $1 \%, 1.5 \%$ and $2 \%$ resulted in the highest amount of L-asparaginase production from Aspergillus terreus MTCC 1782 and Aspergillus terreus [26,37].

Effect of different amino acids and element supplementations on L-asparaginase production: Data illustrated in Table (3) showed effect of different amino acids on L-asparaginase production. The highest L-asparaginase production ( $15 \%$ increases) was achieved with arginine, while isoleucine and cysteine strongly inhibited enzyme production by $69 \%$ and $72 \%$, respectively. Moreover, Addition of arginine at a

\begin{tabular}{|c|c|c|c|c|c|c|c|c|c|}
\hline $\begin{array}{c}\text { L-asparagine } \\
\text { (\%) }\end{array}$ & $\begin{array}{c}\text { L-asparaginase } \\
(\mathrm{U} / \mathrm{ml})\end{array}$ & Nitrogen sources & $\begin{array}{c}\text { L-asparaginase } \\
\text { (U/ml) }\end{array}$ & Carbon source & \begin{tabular}{|c|}
$\begin{array}{c}\text { L-asparaginase } \\
(\mathrm{U} / \mathrm{ml})\end{array}$ \\
\end{tabular} & Suppl. elements & $\begin{array}{c}\text { L-asparaginase } \\
(\mathrm{U} / \mathrm{ml})\end{array}$ & Amino acids & $\begin{array}{c}\text { L-asparaginase } \\
\text { (U/ml) }\end{array}$ \\
\hline $\begin{array}{l}0.5 \\
1.0 \\
1.6 \\
2.0 \\
2.5\end{array}$ & $\begin{array}{l}17.51 \\
39.39 \\
35.75 \\
29.62 \\
29.18\end{array}$ & $\begin{array}{l}\text { Without nitrogen } \\
\text { Peptone } \\
\text { Beef extract } \\
\text { Yeast extract } \\
\text { Urea } \\
\text { Ammonium sulphate } \\
\text { Diammonium citrate } \\
\text { Sodium nitrate } \\
\text { Ammonium nitrate } \\
\text { L-asparagine }\end{array}$ & $\begin{array}{c}1.17 \\
16.34 \\
9.48 \\
17.51 \\
6.13 \\
21.45 \\
18.24 \\
7.59 \\
20.72 \\
33.85\end{array}$ & \begin{tabular}{|c|} 
Without carbon \\
Raffinose \\
Xylose \\
Mannitol \\
Mannose \\
Sucrose \\
Maltose \\
Sorbose \\
Lactose \\
Galactose \\
Fructose \\
Starch \\
Pectin \\
Cellulose \\
Dextrose
\end{tabular} & $\begin{array}{l}29.33 \\
22.18 \\
23.34 \\
14.15 \\
17.65 \\
28.74 \\
21.89 \\
25.09 \\
23.34 \\
32.83 \\
26.26 \\
26.69 \\
28.45 \\
17.79 \\
31.08\end{array}$ & $\begin{array}{c}\text { Control } \\
\mathrm{MgCl}_{2} \\
\mathrm{LiCl}^{2} \\
\mathrm{CaCl}_{2} \\
\mathrm{~K}_{2} \mathrm{HPO}_{4} \\
\mathrm{BaCl}_{2} \\
\mathrm{NaCl}\end{array}$ & $\begin{array}{l}23.34 \\
20.43 \\
16.92 \\
18.53 \\
19.99 \\
11.23 \\
18.82\end{array}$ & $\begin{array}{l}\text { Control } \\
\text { Lysine } \\
\text { Isoleucine } \\
\text { Glycine } \\
\text { Thiamine } \\
\text { Arginine } \\
\text { Treptophane } \\
\text { Proline } \\
\text { Glutamic acid } \\
\text { Cystine } \\
\text { Methonine }\end{array}$ & $\begin{array}{c}23.10 \\
23.19 \\
7.29 \\
17.95 \\
19.69 \\
35.16 \\
24.66 \\
14.88 \\
15.90 \\
6.57 \\
25.53\end{array}$ \\
\hline
\end{tabular}

Table 3: Effect of different concentrations of substrate, nitrogen sources, carbon sources, supplementation elements and amino acids on L-asparaginase production. 
Citation: Abbas Ahmed MM, Nageh Abo Dahab F, Taher Taha M, Fareed Hassan SM (2015) Production, Purification and Characterization of L-Asparaginase from Marine Endophytic Aspergillus sp. ALAA-2000 under Submerged and Solid State Fermentation. J Microb Biochem Technol 7: 165-172. doi:10.4172/1948-5948.1000199

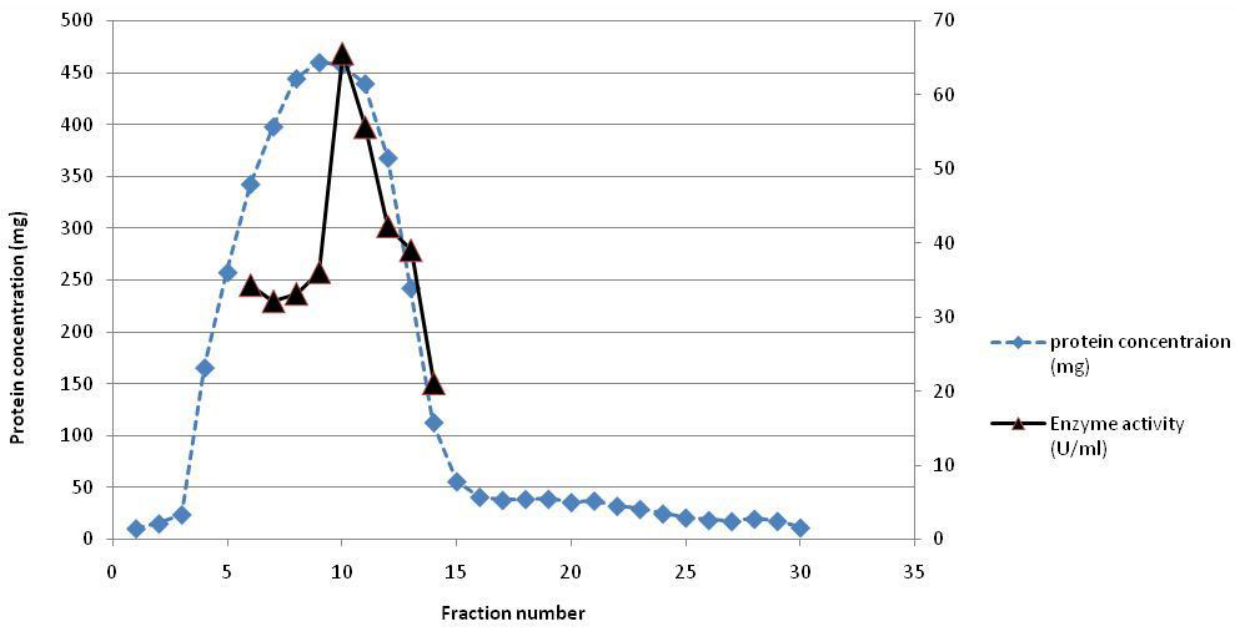

Figure 2: Elution diagram of L-asparaginase using Sephadex G-200 column chromatography.

concentration of $0.15 \%$ achieved the highest enzyme production $(44.8$ $\mathrm{U} / \mathrm{ml})$. The maximum L-asparaginase production was achieved with $1 \% \mathrm{~L}$-asparagine., while lower or higher L-asparagine concentrations did not increase the productivity. On the other hand, all metal supplementations under study $\left(\mathrm{MgCl}_{2}, \mathrm{LiCl}, \mathrm{CaCl}_{2}, \mathrm{~K}_{2} \mathrm{HPO}_{4}, \mathrm{BaCl}_{2}\right.$, and $\mathrm{NaCl}$ ) resulted in a severe decrease in L-asparaginase productivity from 23.34 to $20.43,16.92,18.53,19.99,11.23$ and $18.82 \mathrm{U} / \mathrm{ml}$, respectively (Table 3).

Amino acids are common growth factor required for the biosynthesis of enzyme; hence the yield of L-asparaginase was varied according to the nature of amino acids. L-Asparagine and arginine stimulate L-asparaginase production in Aspergillus sp. ALAA-2000 strain to (33.85 and 35.16), respectively. Anamika et al. [31] reported $\mathrm{L}$-asparagine as the best nitrogen source for $\mathrm{L}$-asparaginase production by Aspergillus terreus in modified czapek Dox medium. None of the elements supplementations added to the fermentation medium enhanced the obtained yields of L-asparaginase from Aspergillus sp. ALAA-2000 strain. Varalakshmi and Raju [26] reported that L-asparaginase production by Aspergillus terreus MTCC 1782 was increased with adding magnesium sulphate to the production medium.

Purification of L-asparaginase: Crude extract of Aspergillus sp. ALAA-2000 strain of medium was purified of L- asparaginase by successive steps including, $\left(\mathrm{NH}_{4}\right)_{2} \mathrm{SO}_{4}$ fractionation and gel filtration chromatography (Sephadex G-200). The fraction obtained at saturation $80 \%$ of ammonium sulphate resulted in specific activity of $(0.053 \mathrm{U} /$ $\mathrm{mg})$, (1.11-fold) purification folds, following Sephadex G-200 gel filtration, the purified L-asparaginase obtained exhibited $(13.1 \mathrm{U} / \mathrm{ml})$ of the total initial activity and there was 8.3 -fold increase in purity with $(0.4 \mathrm{U} / \mathrm{mg})$ specific activity (Table 4 and Figure 2). By using molecular markers with known molecular weights (135.0, 100.0, $75.0,63.0,48.0,35.0,25.0$ and $5.0 \mathrm{kDa}$ ), it was determined that the molecular weight of L-asparaginase from the strain Aspergillus sp. ALAA-2000 strain found to be two protein bands onn SDS-PAGE Figure (3) indicating the dimeric nature of enzymes with different molecular weights were $25 \mathrm{kDa}$ (AYA-1) and $31 \mathrm{kDa}$ (AYA-2). Patro and Gupta [35] recommended that ammonium sulphate precipitation at a concentration of $80 \%$ of L-asparaginase produced by Penicillium sp. and reported L-asparaginase with an apparent molecular weight of $66 \mathrm{kDa}$ was purified with total activity $692.77 \mathrm{U}$, total protein $53.3 \mathrm{mg}$,

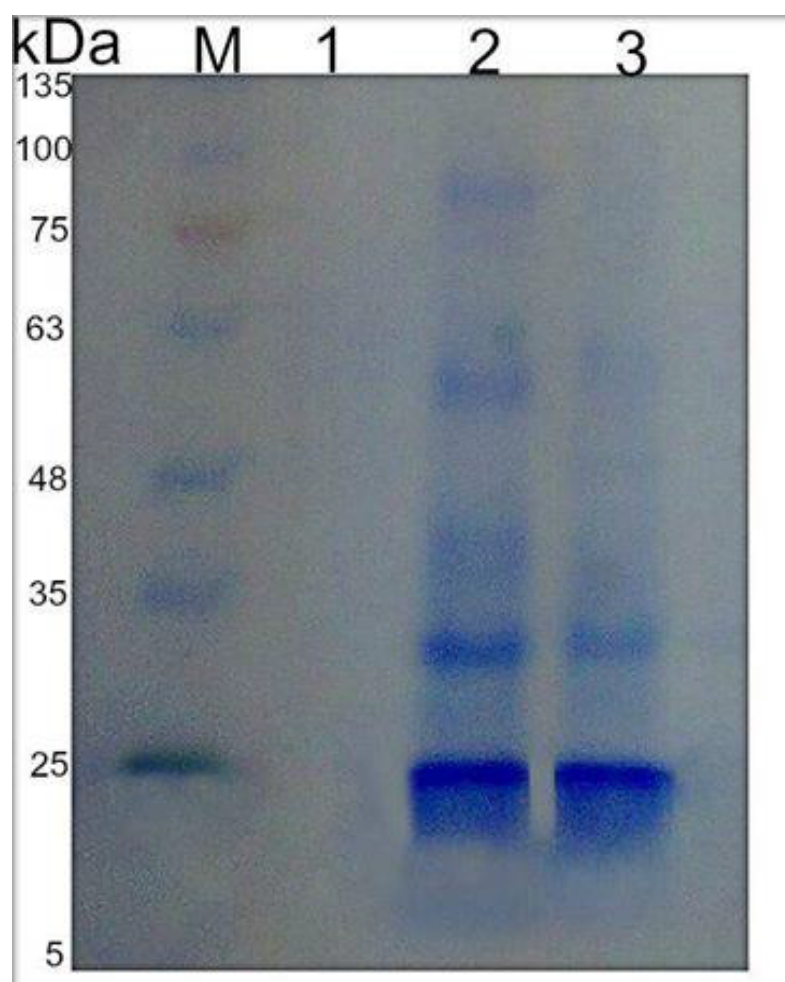

Figure 3: Electrophoretic analysis of L-asparaginase produced by Aspergillus sp. ALAA-2000 at various stages of purification. M, molecular weight markers; $(135.0,100.0,75.0,63.0,48.0,35.0,25.0$ and $5.0 \mathrm{kDa})$; lane 1, crude-enzyme extracts; lane 2, fractional precipitation by $\left(\mathrm{NH}_{4}\right)_{2} \mathrm{SO}_{4} 80 \%$; and lane 3 , partial purified L-asparaginase on Sephadex G-200.

\begin{tabular}{|l|c|c|c|c|c|}
\hline Purification Step & $\begin{array}{c}\text { Total activity } \\
(\mathrm{U})\end{array}$ & $\begin{array}{c}\text { Total protein } \\
(\mathrm{mg})\end{array}$ & $\begin{array}{c}\text { Specific activity } \\
(\mathrm{U} / \mathrm{mg})\end{array}$ & $\begin{array}{c}\text { Yield } \\
(\%)\end{array}$ & Fold \\
\hline Filtrate & 30 & 620 & 0.048 & 100 & 1 \\
$\left(\mathrm{NH}_{4}\right)_{2} \mathrm{SO}_{4}$ precipitation & 24.6 & 457.4 & 0.053 & 82 & 1.11 \\
Sephadex G-200 & 13.1 & 32.3 & 0.4 & 43.6 & 8.3 \\
\hline
\end{tabular}

Table 4: Summary of the purification steps of L-asparaginase. 
Citation: Abbas Ahmed MM, Nageh Abo Dahab F, Taher Taha M, Fareed Hassan SM (2015) Production, Purification and Characterization of L-Asparaginase from Marine Endophytic Aspergillus sp. ALAA-2000 under Submerged and Solid State Fermentation. J Microb Biochem Technol 7: 165-172. doi:10.4172/1948-5948.1000199

specific activity $12.99 \mathrm{U} / \mathrm{mg}$, purification 1.77 -fold and yield $74.85 \%$ after Sephadex G-100 gel filtration. Akilandeswari et al. [36] showed the molecular weight of $\mathrm{L}$-asparaginase produced by $A$. niger is $48 \mathrm{kDa}$ while Devi and Azmi [38] represented L-asparaginase dimeric with two distinct bands of molecular weights 40.2 and $39.8 \mathrm{kDa}$ were purified from Erwinia carotovora MTCC 1428 by total activity 0.34 and total protein $0.91 \mathrm{mg}$.

Characterization of purified L-asparaginase: Due to the purification L-asparaginase showed two protein bands an SDS-PAGE indicating the dimeric nature of enzyme with different molecular weights of $25 \mathrm{kDa}$ (AYA-1) and $31 \mathrm{kDa}$ (AYA-2), these were two maximum peaks of enzyme activity at two different incubation temperatures. The first maximum activity peak was recorded at $47^{\circ} \mathrm{C}$ and the other was noticed at $67^{\circ} \mathrm{C}$. However, both form of L-asparaginase activities were gradually decreased at the optimum incubation temperature. The thermo stability of L-asparaginase activities showed in Table (5). A wide range of $\mathrm{L}$-asparaginase thermo stability from $\left(30\right.$ to $\left.60{ }^{\circ} \mathrm{C}\right)$ and higher than this temperature stability gradually decreased, maximum thermo stability of L-asparaginases at 30,40 and $50{ }^{\circ} \mathrm{C}$ by $100 \%, 100 \%$ and $111 \%$, respectively. L-Asparaginase activities were decreased (30\%) after incubation at $90^{\circ} \mathrm{C}$ for $60 \mathrm{~min}$.

L-asparaginase activities at different $\mathrm{pH}$ values $(3,4,5,6,7,8,9$, 10, 11, and 12) were determined. Results in Table (5), indicated that L-asparaginase showed two-peak activities curve at two different $\mathrm{pH}$ values 6 and 10 with activities of $128 \%$ and $118 \%$, respectively. Which indicated that marine endophytic Aspergillus sp. ALAA2000 strain produced two types of L-asparaginase one thermo stable alkaline L-asparaginase at $\mathrm{pH} 10$ and $67^{\circ} \mathrm{C}$ (AYA-2) and other natural

\begin{tabular}{|c|c|c|c|}
\hline $\begin{array}{c}\text { Thermo } \\
\text { stability }\end{array}$ & $\begin{array}{c}\text { L-asparaginase relative } \\
\text { activities (\%) }\end{array}$ & $\mathbf{p H}$ & $\begin{array}{c}\text { L-asparaginase relative } \\
\text { activities (\%) }\end{array}$ \\
\hline 20 & 70 & 3 & 72.9 \\
30 & 100 & 4 & 78.7 \\
40 & 100 & 5 & 82.9 \\
50 & 111 & 6 & 128 \\
60 & 93 & 7 & 95.2 \\
70 & 83 & 8 & 100 \\
80 & 50 & 9 & 117.3 \\
90 & 30 & 10 & 118 \\
& & 12 & 102.4 \\
& & & 80.5 \\
\hline
\end{tabular}

Table 5: Effect of thermo stability and different $\mathrm{pH}$ values on L-asparaginase activities.

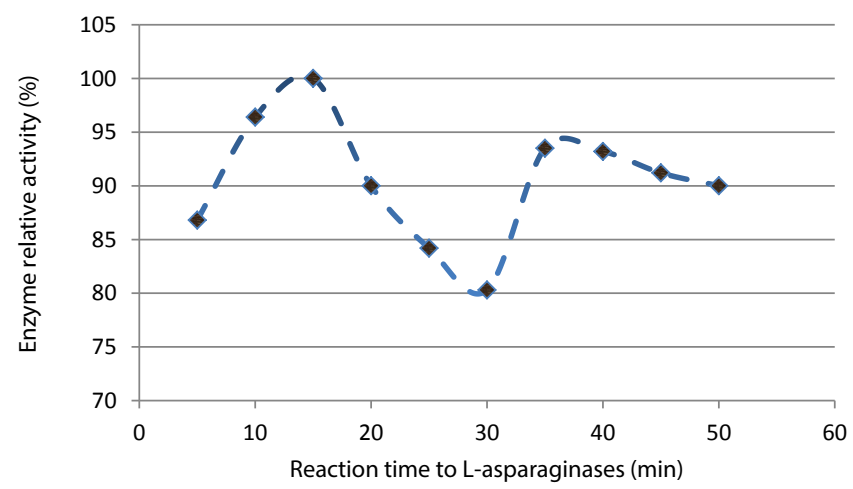

Figure 4: Effect of reaction time on L-asparaginase activities.
L-asparaginase, which exhibited its maximum activity at $\mathrm{pH} 6$ and 47 ${ }^{\circ} \mathrm{C}$ (AYA-1). Moreover, Figure (4) showed that, the activity of partially purified L-asparaginases were recorded at 15 and 35 minutes, which increased up to $100 \%$ and $93 \%$, respectively. These, results may be attributed to the production of dimeric form of L-asparaginases by marine Aspergillus sp. ALAA-2000 strain. On the other hand, the effect of different concentrations of L-asparagine $0.26,0.64,1.28,2.55$, 3.83 and $5.10 \mathrm{mg} / \mathrm{ml}$, on the activity of L-asparaginase was detected. The activities of both L-asparaginases were increased with increasing substrate concentration to $1.28 \mathrm{mg} / \mathrm{ml}$ of L-asparagine. Different partially purified enzyme concentrations $(0.01,0.1,0.15,0.25,0.5$ and $0.2 \mathrm{ml}$ ) of L-asparaginase were attempted in the enzymatic reaction with asparagine at concentration of 0.85 , the suitable enzyme concentration in the reaction mixture that supported the highest activity was 129.9 produced by $0.15 \mathrm{ml}$.

The effect of $\mathrm{Ni}^{2+}, \mathrm{Ba}^{2+}, \mathrm{Ca}^{2+}, \mathrm{Na}^{+}, \mathrm{Co}^{2+}, \mathrm{Mn}^{2+}$, and $\mathrm{Mg}^{2+}$ with final concentration of $0.5 \mathrm{mM}$ of each cation on partially purified $\mathrm{L}$-asparaginase activities were studied .Compared to control, only $\mathrm{Ni}^{2+}$ achieved increase in the L-asparaginase activity about $16 \%$, however other cations inhibited enzyme activity. The highest inhibition was $22 \%$ achieved by $\mathrm{Na}^{+}$. The effect of different concentrations of EDTA $(0.0001$, $0.001,0.005,0.01,0.05$, and $0.1 \mathrm{M}$ ) on the activities of partially purified L-asparaginase, results indicated that different EDTA concentrations have no effect on L-asparaginase activities which means that enzyme activity is not dependent on di or trivalent ions. The parameters of purified L-asparaginase were optimized for AYA-1 and AYA2 (for AYA-1 optimal $\mathrm{pH} 6$, stable in $\mathrm{pH}$ range of 6.0 to 8.0, optimal temperature equal to $47^{\circ} \mathrm{C}$ and thermal stability in the range of 30 to $60^{\circ} \mathrm{C}$ for $60 \mathrm{~min}$ ) and AYA-2 enzyme (optimal pH 10, stable in pH 10.0 - 11.0, optimal temperature equal to $67^{\circ} \mathrm{C}$ and thermal stability in the range of 30 to $60^{\circ} \mathrm{C}$ for $60 \mathrm{~min}$ ). About $30 \%$ and $28 \%$ of L-asparaginase activities decline after incubation at $70{ }^{\circ} \mathrm{C}$ for $30 \mathrm{~min}$ and $80{ }^{\circ} \mathrm{C}$ for $5 \mathrm{~min}$, respectively. Optimum incubation temperature for purified L-asparaginase from Penicillium sp. and Aspergillus niger was reported to be 37 and $35{ }^{\circ} \mathrm{C}$, respectively [35,36]. The purified L-asparaginase from Penicillium brevicompactum NRC 829 was active at a wide range of temperature from 30 to $75^{\circ} \mathrm{C}$ with an optimum at $37^{\circ} \mathrm{C}$ and about $35 \%$ of its activity still present at $70^{\circ} \mathrm{C}$ but it lost its activity at $90^{\circ} \mathrm{C}$ and proved to be metaloenzyme due to the sever inhibition in its activity in the presence of EDTA [32]. On the other hand, Suchita et al. [39] and Kumar et al. [18] reported that L-asparaginase produced by Erwinia carotovora and Streptomyces radiopugnans MS1 non metaloenzymes. Akilandeswari et al. [36] reported the $\mathrm{pH} 8$ is best value for maximum activity of L-asparaginase produced by $A$. niger.

\section{References}

1. Upm-Makna (2010) Cancer research laboratory, Institute of Bioscience

2. Weng CJ, Chau CF, Yen GC, Liao JW, Chen DH, et al. (2009) Inhibitory effects of ganoderma lucidum on tumorigenesis and metastasis of human hepatoma cells in cells and animal models. J Agric Food Chem 57: 5049-5057.

3. Liu K, Ding X, Deng B, Chen W (2009) Isolation and characterization of endophytic taxol-producing fungi from Taxus chinensis. J Ind Microbiol Biotechnol 36: 1171-1177.

4. Nadeem A, Hussain MM, Aslam M, Hussain T, Butt IF, et al. (2009) Association of response to combined interferon alpha- $2 \mathrm{~b}$ and ribavirin therapy in patients of chronic hepatitis $c$ with serum alanine aminotransferase levels and severity of the disease on liver biopsy. J Ayub Med Coll Abbottabad 21: 103-106.

5. Sithranga Boopathy N, Kathiresan K (2010) Anticancer drugs from marine flora: an overview. J Oncol 2010: 214186.

6. McKnight S (2003) Gene switching by metabolic enzymes--how did you get on the invitation list? Cell 114: 150-152. 
Citation: Abbas Ahmed MM, Nageh Abo Dahab F, Taher Taha M, Fareed Hassan SM (2015) Production, Purification and Characterization of L-Asparaginase from Marine Endophytic Aspergillus sp. ALAA-2000 under Submerged and Solid State Fermentation. J Microb Biochem Technol 7: 165-172. doi:10.4172/1948-5948.1000199

7. Holler U, Wright AD, Matthee GF, Konig GM, Draeger S, et al. (2000) Fungi from marine sponges: diversity, biological activity and secondary metabolites. Mycol Res 104: $1354-65$

8. El-Bondkly AM, El-Gendy MM (2010) Keratinolytic activity from new recombinan fusant AYA2000, derived from endophytic Micromonospora strains. Can $J$ Microbiol 56: 748-760.

9. Gulati R, Saxena RK, Gupta R (1997) A rapid plate assay for screening L-asparaginase producing micro-organisms. Lett Appl Microbiol 24: 23-26.

10. El-Bondkly AMA, El-Gendy Mervat MA (2011) Cellulase production from agricultural residues by recombinant fusant strain of a fungal endophyte of the marine sponge Latrunculia corticata for production of ethanol. Antonie van Leeuwenhoek 101: 331-346.

11. El-Bondkly AMA (2012) Molecular identification using ITS sequences and genome shuffling to improve 2-deoxyglucose tolerance and xylanase activity of marine-derived fungus, Aspergillus sp. NRCF5. Appl Biochem Biotechnol 167: 2160-2173.

12. Henry T, Iwen PC, Hinrichs SH (2000) Identification of Aspergillus species using internal transcribed spacer regions 1 and 2. J Clin Microbiol 38: 1510-1515.

13. White TJ, Bruns T, Lee S, Taylor JW (1990) Amplification and direct sequencing of fungal ribosomal RNA genes for phylogenetics. In: PCR Protocols: A Guide to Methods and Applications, eds. Innis MA, Gelfand DH, Sninsky JJ, White TJ. Academic Press, Inc., New York.

14. Wriston JC Jr, Yellin TO (1973) L-asparaginase: a review. Adv Enzymol Rela Areas Mol Biol 39: 185-248.

15. Suntornsuk KW, Hang YD (1997) Purification and characterization of glucoamylase from Rhizopus oryzae mutant. J Sci Soc Thailand: 199-208.

16. Yasser R, Abdel-Fattah, Zakia A (2002) L-Asparaginase production by Pseudomonas aeruginosa in solid-state culture: Evaluation and optimization of culture conditions using factorial designs. Prospects in Biochem 38: 115-122.

17. Gomori G (1955) Preparation of buffers for use in enzyme active studies. In methods in enzymology 1: 138

18. Kumar R, Singh KA, Singh VK, Jagannadham MV (2011) Biochemical characterization of a peroxidase isolated from caribbean plant: Euphorbia cotinifolia. Process Biochem 46: 1350-1357.

19. Laemmli UK (1970) Cleavage of structural proteins during the assembly of the head of bacteriophage T4. Nature 227: 680-685.

20. Strobel G, Daisy B (2003) Bioprospecting for microbial endophytes and their natural products. Microbiol Mol Biol Rev 67: 491-502.

21. El-Bondkly AM, El-Gendy Mervat MAA, Wiese J, Imhoff JF (2012) Phylogenetic diversity and antimicrobial activities of culturable endophytic actinobacteria isolated from different Egyptian marine sponges and soft corals. Australian $\mathrm{J}$ of Basic and Applied Sciences 6: 25-33.

22. El-Gendy Mervat MA (2010) Optimization of process parameters for keratinase produced by endophytic Penicillium spp.Morsy1 under solid state fermentation. Appl Biochem Biotechnol 162: 780-794.

23. El-Gendy Mervat MA (2011) Evaluation of some fungal endophytes of plant potentiality as low-cost adsorbents for heavy metals uptake from aqueous solution. Australian Journal of Basic and Applied Sciences 5: 466-473.

24. El-Gendy Mervat MA (2012) Production of glucoamylase by marine endophytic Aspergillus sp. JAN-25 under optimized solid-state fermentation conditions on agro residues. Australian J of Basic and Applied Sciences 6: 41-54.

25. Thirunavukkarasu N, Suryanarayanan TS, Murali TS, Ravishankar JP, Gummadi SN (2011) L-Asparaginase from marine derived fungal endophytes of seaweeds. Mycosphere 2: 147-155.
26. Varalakshmi V, Raju KJ (2009) optimization of L-asparaginase production by Aspergillus terrus MTCC 1782 using bajra seed flour under solid state fermentation. International $\mathrm{J}$ of Research in Engineering and Technology 2 : 2321-2332.

27. Rani ASA, Lalitha S, Praveesh B (2012) Isolation and screening of $\mathrm{L}$-asparaginase producing fungi from soil samples. International $\mathrm{J}$ of Pharmacy and Pharmaceutical Sciences 4: 279-282.

28. Nathiya K, Sooraj S, Nath J, Angayarkanni, Palaniswamy M (2010) Paddy straw: An inexpensive substrate for the production of L-glutaminase using native strain Aspergillus fumigates. International $\mathrm{J}$ of Pharma and BioSciences volu 2: $1107-1115$

29. Hosamani R, Kaliwal BB (2011) L-Asparaginase an antitumor agent production by Fusarium eouisti using solid state fermentation. International J Drug Discovery 3: 88-99.

30. Negi S, Banerjee R (2010) Optimization of culture parameters to enhance production of amylase and protease from Aspergillus awamori in a single fermentation. African J Biochemistry Research 4: 73-80.

31. Anamika M, Neeraja Y, Swarnalatha J, Venkateshwar S, Venkateswar RL (2013) Optimization of nutrients for L-asparaginase production using Aspergillus Terreus. World $\mathrm{J}$ of Pharmacy and Pharmaceutical Sciences 2: 5582-5590.

32. Elshafei AM, Mohamed MH, Mohamed AA, Dalia MA, Dina HE (2012) Purification, characterization and antitumor activity of L-asparaginase from Penicillium brevicompactum NRC 829. British Microbiology Research J 2: 158 174.

33. Siddalingeshwara KG, Lingappa K (2010) Key fermentation factors for the synthesis of L-asperaginase Antitumer agent SSF methodology. An International $\mathrm{J}$ of Pharmaceutical Sciences 1: 103-112.

34. Luhana KK, Dave AA, Patel KU (2011) Production, purification and characterization of extracellular L-Asparaginase (Anti Cancerous Enzyme) from Aspergillus niger. International J of Chemtech Applications 2: 14-25.

35. Patro KR, Gupta N (2012) Extraction, purification and characterization of L-asparaginase from Penicillium sp. by submerged. International $\mathrm{J}$ for Biotechnology and Molecular Biology Research 3: 30-34.

36. Akilandeswari K, Kavitha K, Vijayalakshmi M (2012) Production of bioactive enzymes L-asparaginase from fungi isolates of water sample through submerged fermentation International $\mathrm{J}$ of Pharmacy and Pharmaceutica Sciences 4: 363-366.

37. Loureiro CB, Kleiton SB, Augusto FA (2012) Purification and biochemical characterization of native and pegylated form of $\mathrm{L}$-asparaginase from Aspergillus terreus and evaluation of its antiproliferative activity. Advances in Microbiology 2: 138-145.

38. Devi S, Azmi W (2012) One step purification of glutaminase free L-asparaginase from Erwinia carotovora MTCC 1428 with anticancer activity. International J of Life and Pharma Research 2: 36-45.

39. Warangkar SC, Khobragade CN (2010) Purification, Characterization, and Effect of Thiol Compounds on Activity of the Erwinia carotovora L-Asparaginase. Enzyme Res 2010: 165878. 